\title{
Varietal Evaluation of China-Aster (Callistephus chinensis Nees.) in Sub-Tropical Region of West Bengal
}

\author{
Aparna Sarkar ${ }^{1 *}$, Raghunath Sadhukhan ${ }^{2}$ and Tapas Kumar Chowdhuri ${ }^{1}$ \\ ${ }^{1}$ Department of Floriculture and Landscape Architecture, ${ }^{2}$ Department of Genetics and Plant \\ Breeding, Bidhan Chandra Krishi Viswavidyalaya, Mohanpur, Nadia-741252, WB, India \\ *Corresponding author
}

\begin{tabular}{|l|}
\hline Ke y w or d s \\
Callistephus \\
chinensis Nees., \\
Cultivars, \\
Evaluation, \\
Vegetative growth, \\
Flowering \\
characters \\
\hline Article Info \\
\hline $\begin{array}{l}\text { Accepted: } \\
\text { 26 May } 2020 \\
\text { Available Online: } \\
\text { 10 June } 2020\end{array}$ \\
\hline
\end{tabular}

\begin{abstract}
The present investigation was carried out during 2017-18 in the floricultural research station of Bidhan Chandra Krishi Viswavidyalaya. Significant variation in vegetative growth was recorded among the cultivars of China aster. Plant height was recorded the maximum $(49.3 \mathrm{~cm})$ in Pink Local. The highest number of leaves $(246.00$ nos./ plant) was observed in Arka Aadya followed by Pink Local (222.0 nos./plant). Number of sprays per plant was found to be the highest in Pink Local (8.7) which was followed by Arka Archana, (7.7) Arka Aadya (7.7) and Arka kamini(7.0). Pink Local variety had better flower diameter and stalk length $(7.8 \mathrm{~cm}$ and $32.3 \mathrm{~cm}$ respectively) followed by Arka Kamini $(6.7 \mathrm{~cm}$ and $32.3 \mathrm{~cm}$ respectively). Flowering duration of Arka Kamini was the longest (32.3 days) followed by Pink Local (29.3days). Vase life of flower was excellent in Arka Archana (12.7 days) which was at par with the Pink Local (12.7 days). Thus the result depicted that Pink Local, Arka Kamini and Arka Poornima are the most suitable cultivars to be grown for cut flower production, whereas Arka Aadya and Arka Archana have greater importance for pot plant production as well as garden decoration in West Bengal.
\end{abstract}

\section{Introduction}

China aster, scientifically known as Callistephus chinensis Nees., belongs to the family Asteraceae, is one of the most demanding winter annual flowers ranks third just next to Chrysanthemum and Marigold (Sheela, 2008). The genus named 'Callistephus' was derived from the greek words 'Kalistos' meaning 'most beautiful' and 'Stephos' meaning 'a crown'. China aster is one of the most preferable commercial flower crops, grown as cut flower, loose flower, bedding plant, floral decoration, bouquets and garland preparation, consisting a wide spectrum of attractive colors including violet, purple, magenda, many shades of pink, pure white, pale blue, mauve, dark blue, scarlet and comparatively longer vase life (Chaitra and Patil, 2007; Dilta et al., 2007). 
China aster being well adapted to diversified soil and climatic condition, it is now-a-days successfully grown in various agro-climatic zones of India. China aster estimated to be commercially grown over an area of 3500 ha in India by marginal and small farmers in Karnataka, Tamil Nadu, Telangana, Andhra Pradesh, Maharashtra and West Bengal (Pratiksha et al., 2017), among which Karnataka itself has covered an area of 1531 ha with a productivity of 9.05 t/ha (Anonymous, 2014).

The demand is increasing day by day for cut flowers of China aster but the production as well as the quality is not up to the mark to meet the need of consumers. The production by means of both quality and yield can be improved by adopting improvised agrotechniques and high yielding cultivars as the productivity is highly dependent over cultivars. Although, there are a number of cultivars of China aster commercially cultivated throughout India, but their performance is region specific.

Therefore, the selection of suitable cultivars for a particular region is very much important through performance studies and recommendations should be given by which maximum profits can be earned. Considering all the facts mentioned above, the present experiment was designed to find out most suitable cultivars to be adapted in West Bengal situation.

\section{Materials and Methods}

The present investigation was carried out in the floricultural research station of Bidhan Chandra Krishi Viswavidyalaya during 201718. Experimental field was laid out in randomized complete block design with Six varieties namely 'Arka Poornima', 'Arka Kamini', 'Arka Aadya' and 'Arka Archana', 'White Local', and 'Pink Local' each having
4 replications and 30 plants per replication at a spacing of $30 \mathrm{~cm} \times 30 \mathrm{~cm}$. Five plants per replication were randomly tagged to be used for recording various observations on growth and flowering parameters. Local varieties of the region such as 'White Local' and 'Pink Local' were taken as check, whereas, rest of the varieties/ entries were collected from IIHR, Hessaraghatta, (4 Nos.) for their comparative performance studies in respect of local cultivars. Newly adopted varieties/entries were to be evaluated with their respective colour group of local ones.

The observations were recorded in terms of plant height $(\mathrm{cm})$, plant spread $\left(\mathrm{cm}^{2}\right)$, no. of leaves plant ${ }^{-1}$, no. of sprays plant ${ }^{-1}$, days to flower bud appearance, days to flower opening, flower diameter $(\mathrm{cm})$, no. of flowers plant $^{-1}$, duration of flowering (days), flower stalk length $(\mathrm{cm})$, vase life in tap water (Days) and colour of the flowers (RHS colour chart). Data was statistically analysed by following Fisher's analysis of Variance Technique as described by Gomez and Gomez (1984).

\section{Results and Discussion}

Comprehensive study in terms of both vegetative growth and flowering parameters of different genotypes of China aster was followed in this experiment to find out the most suitable cultivar for growing commercially in the sub-tropical region of West Bengal. Significant differences were noticed among the treatments for all the characters studied.

\section{Vegetative growth}

The response of different cultivars on behalf of vegetative growth regarding plant height, plant spread, no. of leaves/plant, no. of sprays/plant is mentioned in Table 1. The maximum plant height was observed in cultivar Pink Local $(49.3 \mathrm{~cm})$ over others 
variety, whereas, plant height was recorded minimum in Arka Aadya $(28.0 \mathrm{~cm})$, which was at par with Arka Archana $(31.3 \mathrm{~cm})$. So, the plant height was brought up to $76.2 \%$ more in Pink Local than Arka Aadya.

There is a remarkable influence of different cultivars on plant spread or canopy spread of the plant, which is considered as an important parameter indicating vegetative growth. Canopy spread was assessed the maximum in plants of Pink Local with a mean value of 2652.0 sq.cm which was followed by Arka Archana (2208.7 sq.cm), whereas plant spread was recorded the least in Arka Kamini (1020.0 sq.cm) over other genotypes. So, the cultivar Pink Local have grown more vigorously with an increase in plant spread up to $64.38 \%$ more than Arka Aadya as well as $160.0 \%$ over Arka Kamini.

Regarding leaf production as illustrated in Table 1, response was received the best from the plants of cultivar Arka Aadya (246.0), which was at par with the mean number of leaves produced by Arka Kamini (227.33). Whereas, the minimum number of leaf production was observed in Arka Poornima (52.0). Thus, performance of Arka Aadya showed a significant increase in leaf production up to $373.0 \%$ and $10.8 \%$ over Arka Poornima and Pink Local respectively. White flowering cultivars as mentioned in Table 3, if considered, Arka Archana showed better response among all with an increase in mean leaf production up to $297.44 \%$ over Arka Poornima and $51.96 \%$ while compared to White Local. On the contrary, mean leaf production was brought in White Local up to 161.53\% more than Arka Poornima.

Production of flowering shoots or sprays was greatly influenced by different genotypes as revealed in Table 1. The recorded data shows that the highest number of sprays or flowering shoots was produced in Pink Local (8.7) and it was followed by Arka Aadya (7.7) which was at par with Arka Archana (7.7). The minimum number of sprays was developed in Arka Poornima (6.6) and at par with White Local (6.7). Thus, the result indicates that Pink Local performed better in terms of flowering shoot production by $13.0 \%$ more than Arka Aadya.

\section{Flowering behavior, vase life and visible colour of the flowers}

In this experiment, flowering parameters as evaluated by means of days to flower bud appearance, days to first flower open, total number of flowers per plant, flower diameter, flower stalk length are represented in Table 2 and duration of flowering, vase life and colour group of flowers are reflected in Table 3 as well. Data collected on the parameters of flower quality were subjected to statistical analysis at $5 \%$ probability level of significance.

Mean number of days required for flower bud initiation shows a significant difference among all the genotypes selected for evaluation. Recorded data depicts that the cultivar Arka Archana required the minimum number of days for flower bud initiation $(80.0$ days) which was followed by White Local (84.6 days), Pink Local (85.3 days) and Arka Aadya (86.3 days). Whereas, requirement of maximum days for flower bud initiation was found in Arka Poornima (112.3 days). So, the observations clearly indicate that among all the genotypes, earlier flower bud initiation was documented in Arka Archana which was brought up to 32.3 days earlier over Arka Poornima and 28.0 days earlier than Arka Kamini.

A remarkable difference among the genotypes regarding performance in terms of number of days required from transplanting to first flower opening shows that the cultivar White 
Local needed lesser number of days for first flower opening (90.0 days) which was found to be at par with the response of Arka Archana (95.6 days) and the later one was recorded to be at par with Pink Local (98.0 days) and Arka Aadya (99.0 days). Whereas, the data implicated that Arka Kamini required the maximum number of days for flower opening (137.6 days) and it was at par with Arka Poornima consisting a mean duration of 130.0 days from tranplanting to first flower opening. Thus, the observations clearly shows that among all the genotypes, earlier flower opening was documented in White Local which bloomed up to 47.6 days earlier over Arka Kamini and 40.0 days earlier than Arka Poornima.

Mean number of flowers per plant recorded the maximum (Fig.1) in Arka Kamini (45.7) which was followed by Pink Local (42.7), whereas least number of flower obtained in Arka Poornima (22.3) over others genotypes. So, the cultivar Arka Kamini acted better with up to $109.0 \%$ more number of flowers per plant over Arka Poornima.

Regarding flower diameter as shown in Fig. 2, Pink Local accounted with the highest flower diameter $(7.8 \mathrm{~cm})$ followed by White Local $(7.5 \mathrm{~cm})$, whereas, flower diameter was recorded the least in Arka Archana $(6.10 \mathrm{~cm})$ which was at par with Arka Aadya (6.2cm), Arka Kamini $(6.3 \mathrm{~cm})$ and Arka Poornima $(6.4 \mathrm{~cm})$. Thus the result exhibited that more elevated flower diameter might be achieved from Pink Local bringing up to $21.98 \%$ over Arka Aadya while pink blooming cultivars are compared.

Different genotypes of China aster evolved a notable change in flower stalk length (Fig. 2). The longest flower stalk was measured in the cultivar Pink Local as well as Arka Kamini $(32.3 \mathrm{~cm})$ which was closely followed by Arka Poornima $(31.7 \mathrm{~cm})$ and White Local (30.cm). The result depicts that stalk length was recorded the minimum in Arka Aadya $(18.0 \mathrm{~cm})$ followed by Arka Archana (19.33 $\mathrm{cm})$. The recorded data reveals that Arka Kamini as well as Pink Local has produced the enlarged stalk by $15.46 \%$ over Arka Aadya.

Mean duration of flowering shows a significant difference among all the genotypes selected for evaluation. The maximum duration of flowering (32.3 days) was recorded from the plants of Arka Kamini which was followed by Pink Local consisting a mean flowering duration of 29.3 days. Flowering duration was found to be the least in Arka Archana (19.3 days) which was at par with White Local (20.0 days). The collected data clearly indicates that among all the genotypes, production of flowers for a longer duration was obtained from Arka Kamini which was brought up to $68.42 \%$ over Arka Archana.

Vase life of the cut flower was also remarkably influenced by different genotypes as reflected in Table 3 (Fig. 2), the maximum vase life (12.7days) was observed in the flowers of both cultivar Pink Local and Arka Archana which was at par Arka poornima (11.7days). Whereas, the minimum vase life was recorded in Arka Aadya (9.0 days) which was at par with Arka Kamini (10.0 days) and White Local (9.7 days). Here, the percentage increase in vase life of flowers of Pink Local as well as Arka Archana was noted to be $40.78 \%$ over Arka Aadya.

Colour of the flowers from different genotypes collected for evaluation as highlighted in Table 3 (Fig. 3), was mentioned by comparing with a standard colour chart (Royal Horticulture Society, London). As per the evaluation, Arka Poornima and Arka Archana were catagorised under white flowering group along with 
White Local, whereas, Arka Aadya came under the pink flowering group with Pink Local. Arka Kamini alone belongs to Purple group.

Although the production and quality of flowers highly depends upon the cultivars, it is also influenced by weather or climatic condition and soil type of a particular region. A number of cultivars are commercially grown throughout India and their performance in diverse regions such as Karnataka, Maharashtra, Delhi, Tamil Nadu, Hyderabad, Uttarakhand, Hill region of Himachal Pradesh has been evaluated by several researcher and scientists till date, but in West Bengal it is still to find out the most suitable cultivar for growing in commercial scale to earn more profit. In this present investigation, the research findings has highlighted that Pink Local was the tallest growing cultivar with maximum plant spread while Arka Aadya presented itself as the dwarf cultivar among the mentioned genotypes with less plant spread as compared to Pink Local. Although the leaf production was higher in Arka Aadya, maximum number of flowering shoot was produced by Pink Local. Similarly, the white blooming cultivars if compared, Arka Archana was found to be spreading in nature with higher leaf content and spray content, whereas, White Local was noticed to grow taller than rest two cultivars.

Overall performance of all the genotypes in this sub-tropical region of West Bengal differ to some extend when compared to the research findings of other regions or states, however there was a strong impact of genotypic variation in vegetative growth as well as flowering characters. Plant height being controlled by genetic factors, a significant variation was marked in the present investigation. An experiment conducted by Kishanswaroop et al., (2004) reported a variation in plant height among different cultivars of China aster. Varietal evaluation done by Munikrishnappa et al., (2013) also showed that there was a remarkable difference in plant height among the cultivars of China aster. Genotypic variation regarding plant height was also reported by Poonima et al., (2006), Chavan et al., (2010), Kulkarni et al., (2004), Zosiamliana et al., (2013), Bhargav (2014), Chowdhuri et al., (2016), Kaushal et al., (2014) Rai and Chaudhary (2017), and Shankari et al., (2019).

Genetic makeup of a cultivar is highly responsible for its better performance, genotypic factors influence the spreading nature of a plant which farther more plays a great role in enhancing the productivity and quality of the flower. Near about similar observations was reported by Chavan et al., (2010) where the maximum plant spread was recorded in variety Phule Ganesh Pink. Another investigation for varietal evaluation of China aster carried out by Zosiamliana et al., (2013) also reported a significant variation among the cultivars regarding plant spread. Genetic variation was also found by Bhargav (2014), Kaushal et al., (2014), Rai and Chaudhary (2017), Shankari et al., (2019) and Chowdhuri et al., (2016) in China aster

The present investigation pointed that increase in production of leaves is positively related to plant height and plant spread among the cultivars with some exception. Thus, the total number of leaves in plant is also dependent over genetic factors. Evaluation of different genotypes of China aster in terms of leaf production was carried out previously by Poornima et al., (2006) where a sharp variation in leaf production among different varieties was reported. Similar effect was observed in the findings of Zosiamliana et al., (2013) who recorded the maximum number of leaves in Phule Ganesh Violet. Observation was also recorded by Kishanswaroop et al., (2004) and Chowdhuri et al., (2016) regarding the performance of a number of 
cultivars with respect to leaf production in China aster.

The result reflected a remarkable change in production of sprays or flowering shoots among different cultivars of China aster in the present experiment when external factors were constant for all. Thus, the variation noticed might be due to variable genetic makeup of different cultivars. Similar kind of observations was recorded by Zosiamliana et al., (2013) where the primary branches and secondary branches were counted and was found the highest in Phule Ganesh Pink. The present investigation was in line with the findings of Ravikumar (2002), Munikrishnappa et al., (2013), Poornima et al., (2006), Chavan et al., (2010), Chowdhuri et al., (2016) and Kaushal et al., (2014) who had worked in China aster.

Flowering parameters if considered, the result shows that Pink Local performed superior among all the cultivars which bloomed earlier with a good quality and quantity flowers having the longest stalk and the highest vase life. Among the white flowering group, Arka Archana though started to bloom earlier than others and produced a large quantity of flowers consisting of the highest vase life but response of Arka Poornima found better regarding flower quality in terms of flower size, stalk length, total duration of flowering as well as vase life even though it was a late bloomer and total flower production was less.

However, overall performance of White Local was inferior over others. Whereas, Arka Kamini was late blooming cultivar which produced a large number of flowers with desirable size and stalk length and also having a good vase life. Number of days required for flower bud initiation and simultaneously first flower opening determines whether the plant is early blooming or late blooming. However, this behavior of plant highly depends upon varietal traits. Singh et al., (2014) reported in his findings that earliness or delay in first flower opening effectively helps plant to manipulate the duration of flowering and thus enhancing the net profit. Another investigation conducted by Dhiman (2003) highlighted that earliness in plant might take place due to more accumulation of dry matter content. An investigation conducted by Kaushal et al., (2014) in China aster reported a significant variation among different genotypes regarding earliness in flowering which was in line with the present experiment. The observation was supported by Bhargav (2014), Zosiamliana et al., (2013), Kumar and Patil (2003), Chowdhuri et al., (2016) and Khangjarakpam et al., (2014) who reported their findings in China aster.

Production of number of flowers is directly related to vegetative growth and it highly depends upon the inherent genetic traits of different cultivars. Observations recorded in present experiment, marked a significant variation among the cultivars take for evaluation where Arka Kamini obtained the highest number of flowers and Arka Poornima produced the minimum number of flowers. The present investigation was in line with the findings of Kaushal et al., (2014).

Zosiamliana et al., (2013) conducted an experiment on varietal evaluation of China aster in Hyderabad region and reported a remarkable variation in performance of cultivars towards flower production. Genotypic variation towards the influence in flower production of China aster cultivars was also noticed by Poornima et al., (2006), Munikrishnappa et al., (2014), Pandey and Rao (2014), Rai and Chaudhary (2017), Chavan et al., (2010), Chowdhuri et al., (2016) and Dharmendra et al., (2019). 
Table.1 Performance of different genotypes of China aster on vegetative growth

\begin{tabular}{|c|c|c|c|c|}
\hline $\begin{array}{l}\text { Name of the } \\
\text { genotypes }\end{array}$ & $\begin{array}{l}\text { Plant height } \\
\text { (cm) }\end{array}$ & $\begin{array}{l}\text { Plant spread } \\
\text { (sq. cm) }\end{array}$ & $\begin{array}{l}\text { No. of leaves } \\
\text { plant }^{-1}\end{array}$ & $\begin{array}{l}\text { No. of spray } \\
\text { plant }^{-1}\end{array}$ \\
\hline Arka Poornima & 34.7 & $1,762.0$ & 52.0 & 6.6 \\
\hline Arka Kamini & 43.0 & $1,020.0$ & 227.3 & 7.0 \\
\hline White Local & 42.0 & $1,932.3$ & 136.0 & 6.7 \\
\hline Arka Aadya & 28.0 & $1,613.3$ & 246.0 & 7.7 \\
\hline Arka Archana & 31.3 & $2,208.7$ & 206.7 & 7.7 \\
\hline Pink Local & 49.3 & $2,652.0$ & 222.0 & 8.7 \\
\hline $\mathrm{SE}( \pm)$ & 1.46 & 62.934 & 6.23 & 0.31 \\
\hline CD at $5 \%$ & 4.58 & 200.873 & 19.89 & 0.99 \\
\hline CV $(\%)$ & 6.53 & 5.846 & 5.94 & 7.11 \\
\hline
\end{tabular}

Table.2 Performance of different genotypes of China aster on flowering behavior

\begin{tabular}{|l|c|c|c|c|c|}
\hline $\begin{array}{l}\text { Name of the } \\
\text { genotypes }\end{array}$ & $\begin{array}{c}\text { Days to } \\
\text { flower bud } \\
\text { appearance }\end{array}$ & $\begin{array}{c}\text { Days to } \\
\text { flower } \\
\text { opening }\end{array}$ & $\begin{array}{c}\text { No. of } \\
\text { flowers } \\
\text { plant }^{-1}\end{array}$ & $\begin{array}{c}\text { Flower } \\
\text { diameter } \\
\text { (cm) }\end{array}$ & $\begin{array}{c}\text { Flower stalk } \\
\text { length } \mathbf{( c m )}\end{array}$ \\
\hline Arka Poornima & 112.3 & 130.0 & 22.3 & 6.4 & 31.7 \\
\hline Arka Kamini & 108.0 & 137.6 & 45.7 & 6.3 & 32.3 \\
\hline White Local & 84.6 & 90.0 & 28.0 & 7.5 & 30.0 \\
\hline Arka Aadya & 86.3 & 99.0 & 31.7 & 6.2 & 18.0 \\
\hline Arka Archana & 80.0 & 95.6 & 38.7 & 6.1 & 19.3 \\
\hline Pink Local & 85.3 & 98.0 & 42.7 & 7.8 & 32.3 \\
\hline SE( $\mathbf{( )}$ & 2.52 & 1.85 & 1.76 & 0.09 & 0.84 \\
\hline CD at 5\% & 8.05 & 5.92 & 5.62 & 0.31 & 2.68 \\
\hline CV $(\%)$ & 4.71 & 2.96 & 8.75 & 2.56 & 5.76 \\
\hline
\end{tabular}

Table.3 Flowering duration, Vase life and Flower colour (RHS colour chart) of different Genotypes of China aster

\begin{tabular}{|l|c|c|c|c|}
\hline $\begin{array}{l}\text { Name of the } \\
\text { genotypes }\end{array}$ & $\begin{array}{c}\text { Duration of } \\
\text { flowering(Days) }\end{array}$ & $\begin{array}{c}\text { Vase life in tap } \\
\text { water (Days) }\end{array}$ & $\begin{array}{c}\text { RHS colour } \\
\text { chart No. }\end{array}$ & $\begin{array}{c}\text { RHS colour } \\
\text { chart group }\end{array}$ \\
\hline Arka Poornima & 23.0 & 11.7 & $999 \mathrm{D}$ & White group \\
\hline Arka Kamini & 32.3 & 10.0 & $71 \mathrm{~A}$ & Purple group \\
\hline White Local & 20.0 & 9.7 & $155 \mathrm{D}$ & White group \\
\hline Arka Aadya & 23.7 & 9.0 & $70 \mathrm{C}$ & Pink group \\
\hline Arka Archana & 19.3 & 12.7 & $999 \mathrm{D}$ & White group \\
\hline Pink Local & 29.3 & 12.7 & $70 \mathrm{C}$ & Pink group \\
\hline SE( $\mathbf{( )}$ & 0.89 & 0.63 & & \\
\hline CD at 5\% & 2.84 & 2.00 & & \\
\hline CV $(\%)$ & 6.28 & 9.66 & & \\
\hline
\end{tabular}




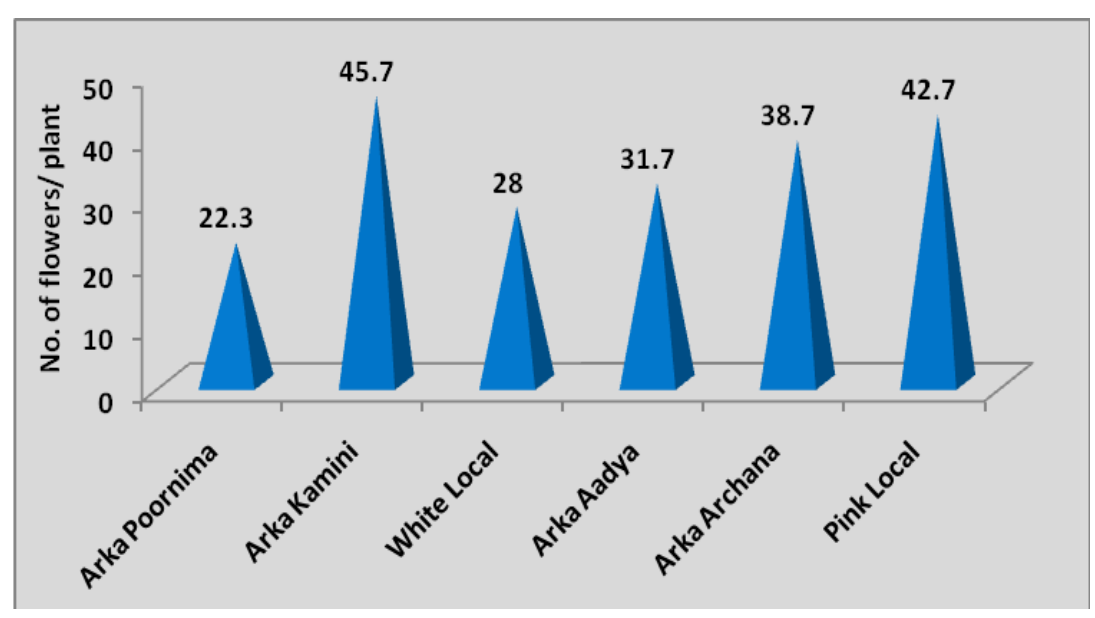

Fig.1 Flower production of different genotypes of China aster

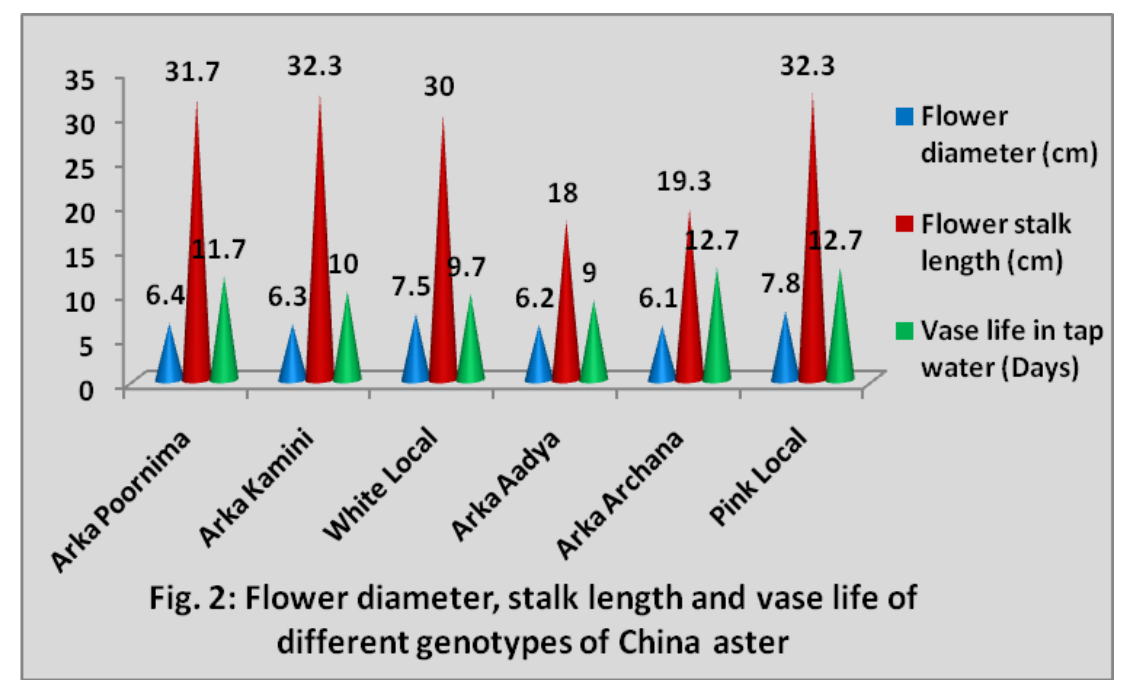

Fig.2 Flower diameter, stalk length and vase life of different genotypes of China aster

Measurement of flower diameter denotes the size of a flower which comes under quantitative traits and greatly influenced by genetic makeup of plants. It is considered as an important parameter for better grading of flowers to fetch higher market value. Here in this experiment, Pink Local produced larger sized flowers if compared to others which were followed by White Local. Flower size was recorded the smallest in Arka Archana, Arka Aadya, Arka Poornima.

The result depicts that changes in size of flowers might be directly linked with vegetative growth with some exceptions, thereby increasing photosynthates which plays a vital role in improving flower size. The observation recorded was supported by the findings of Kishanswaroop et al., (2004) who conducted an experiment in China aster to evaluate the best performing cultivar in Delhi region.

Similarly the present data was in line with the reports of Kaushal et al., (2014), Zosiamliana et al., (2013), Poornima et al., (2006), Bhargav (2014) Rai and Chaudhary (2017), Kumar et al., (2017) and Sankari et al., (2019) in China aster. Flowering duration determines the availability of flowers in the 
market for longer period. The recorded data as described above highlighted that there is a remarkable variation among the cultivars regarding mean flowering duration and it clearly shows that flowering duration is very much dependent upon genetic makeup of different cultivars. The result reflected that Arka Kamini though came to bloom very late, it produced flower for longer duration as well as cultivar Pink Local produced flowers for longer duration than others variety, whereas, another delay flowering genotype Arka Poornima produced flowers for longer time among the white blooming cultivars. So, delay flowering cultivars remained in flowering stage for longer duration. The observation regarding flowering duration was in line with the findings of Rai and Chaudhary (2017), Zosiamliana et al., (2013), Pandey and Rao (2014), Pratiksha et al., (2017), Chowdhuri et al., (2016), Sankari et al., (2019) and Kumar et al., (2017) in China aster.

Vase life of the flowers if considered, since the same vase solution was provided and similar external factors were maintained for all cultivars, the variation noticed in vase life might be due to diverse genetic makeup of the mentioned cultivars. The results obtained from present investigation was in conformity with the findings of Kishanswaroop et al., (2004), Zosiamliana et al., (2013), Rai and Chaudhary (2017), Sankari et al., (2019), Bhargav et al., (2018), Chowdhuri et al., (2016) and Kaushal et al., (2014).

According to the observations recorded, overall performance of Pink Local was marked the best as it was tall growing and spreading in nature which produced the maximum number of good quality flowers for longer duration with long stalk and improved vase life. Whereas, among the white flowering genotypes, response of Arka Poornima was better to produce desirable sized long stalked flowers with good vase life although, production of mean number of flowers was greater in Arka Archana. Arka Kamini was also found to be satisfactory consisting medium tall erect growing plants with good number of flowers with marketable size having long stalk.

So, keeping all in consideration, it can be concluded that Pink Local, Arka Kamini, Arka Poornima are the most suitable cultivar to be grown for cut flower production, whereas Arka Aadya and Arka Archana have greater importance for pot plant production as well as garden decoration in West Bengal.

\section{References}

Anonymous, 2014. Statistical data on horticultural crops in Karnataka State. Department of Horticulture, Lalbagh. Bengaluru. pp. 37.

Bhargav, V. 2014. Effect of different plant spacing and cultivars on growth, flower and seed production of China aster (Callistephus chinensis (L.) Nees.). M.Sc Thesis, Dr. Y. S. Parmar University of Horticulture and Forestry, Nauni, Solan.

Bhargav, V., Sharma, B.P., Dilta, B.S., Gupta, Y.C. and Negi, N. 2016. Effect of different plant spacings and cultivars on growth, flowering and seed production of China aster [Callistephus chinensis (L.) Nees]. Research in Environment and Life Science. 9(8): 970-972.

Chaitra, R. and Patil, V. S. 2007. Integrated nutrient management studies in China aster (Callistephus chinensis Nees) cv. Kamini. Karnataka Journal of Agricultural Sciences. 20(3): 689-690.

Chavan, M. D., Jadhav, P. B. and Rugge, V. C. 2010. Performance of China aster varieties and their response to different levels of nitrogen. Indian Journal of Horticulture, 67: 378-381. 
Chowdhuri, T.K., Rout, B., Sadhukhan R. and Mondal T. 2016. Performance evaluation of different varieties of China aster (Callistephus Chinensis L. Ness) in subtropical belt of West Bengal. International Journal of Pharmaceutical Science Invention. 5(8): 15-18.

Dharmendra, N., Kandpal, K., Hugar, A., Patil, M. G. and Kulkarni, V. 2019. Performance of different varieties of China aster (Callistephus chinensis (L.) Nees) for North eastern dry zone of Karnataka. Journal of Pharmacognosy and Phytochemistry, 8(4): 1486-1494.

Dhiman, M. R. 2003. Assessment of chrysanthemum germplasm for commercial cultivation under Kullu valley condition. Journal of Ornamental Horticulture, New Series, 4(2): 95-97.

Dilta, B.S., Gupta, Y.C. and Sharma, P. 2007. Effect of different planting dates on performance of China aster (Callistephus chinensis Nees) varieties. Asian Journal of Horticulture. 2(2): 245-248.

Gomez, L. A. and Gomez, A. A. 1984. Statistical procedure for Agricultural Research, p-680. John Wiley and Sons, Singapore.

Karrow, P. and Sharma, B. P. 2010. Evaluationn of standard carnation cultivars under protected conditions. Progressive Agriculture, 10: 50-60.

Kaushal, S., Dilta, B. S. Chaudhary, S. V. S., Sharma, B. P. and Gupta, Y. C. 2014. Effect of planting dates on growth and flowering of China aster (Callistephus chinensis (L.) Nees). International Journal of Farm Sciences, 4(1): 60-71.

Khangjarakpam, G., Kumar, R., Seetharamu, G.K., Rao, T.M., Dhananjaya, M.V., Venugopalan, R. and Padmini, K. 2014. Seed setting studies in China aster [Callistephus chinensis (L.) Nees]. Progressive Agriculture. 14(1): 189-
191.

Kishanswaroop, Singh, K. P., Saxena, N. K. and Singh, K. P. 2004. Evaluation of China aster varieties under Delhi condition. Journal of Ornamental Horticulture, 7(1): 127-128.

Kulkarni, B. S., Reddy, B. S., Patil, B. C. and Mathad, G. P. 2004. Performance of China aster cultivars under different environmental conditions. Karnataka Journal of Horticulture, 1(1): 100-103.

Kumar, H. R. and Patil, V. S. 2003. Genetic variability and character association atudies in China aster (Callistephus chinensis) genotypes. Journal of Ornamental Horticulture, 6(3): 222-228.

Kumar, S. V., Pandiyaraj, P. and Theresa, K. 2017. Collection and evaluation of China aster (Callistephus chinensis (L.) Nees) varieties for enhanced yield and quality under tropical condition of Tamil Nadu. Research in Environment and Life Sciences, 10(5): 418-420.

Munikrishnappa, P. M., Patil, A. A., Patil, V. S., Patil, B.N., Channappagoudar, B. B. and Alloli, T. B. 2013. Studies on the growth and yield parameters of different genotypes of China aster (Callistephus chinensis Nees). Karnataka Journal Agricultural Sciences. 26(1): 107-110.

Pandey, N. and Rao, V. K. 2014. Influence of planting geometry on performance of China aster genotypes under mid hill conditions of Uttarakhand. Journal of Hill Agriculture. 5(2): 139-143.

Poornima, G., Kumar, D. P. and Seetharamu, G. K. 2006. Evaluation of China aster (Callistephus chinensis (L.) Nees) genotypes under hill zone of Karnataka. Journal of Ornamental Horticulture, 9(3): 208-211.

Pratiksha Kumari., Kumar R., Rao T.M., Bharathi T.U. Dhananjaya M.V., and Bhargav V. 2017. Evaluation of China aster [Callistephus chinensis (L.) Nees] F1 hybrids and parents for growth, 
flower quality, yield and postharvest life. International Journal of Current Microbiology and Applied Science. 6(8): 1543-1549.

Rai, T.S. and. Chaudhary, S. V. S. 2017. Evaluation of China aster (Callistephus chinensis Nees) cultivars under mid-hill conditions of Himachal Pradesh. The Bioscan. 11(4): 2367-2370.

Ravikumar, 2002. Evaluation of China aster (Callistephus chinensis (L.) Nees) genotypes under dry zone of north Karnataka. M.Sc (Agri.) Thesis, University of Agricultural Science, Dharwad.

Sankari, A., Anand, M., Kavitha, M. and Anita, V. 2019. Per se performance of
China aster (Callistephus chinensis (L.) Nees) varieties for yield under Nilgiris. International Journal of Chemical Studies, 7(3): 1649-1652.

Singh, K. P., Raju, D. V. S., Namita and Janakiram, T. 2014. Determination of genetic variation and floral traits in African marigold (Tagetes erecta). Indian Journal of Agricultural Science, 84(9): 1057-1062.

Zosiamliana, J. H., Reddy, G. S. N. and Rymbai, H. 2013. Study on the performance of some varieties of China aster (Callistephus chinensis Ness) in Andhra Pradesh. Progressive Horticulture. 45(2): 312-316.

\section{How to cite this article:}

Aparna Sarkar, Raghunath Sadhukhan and Tapas Kumar Chowdhuri. 2020. Varietal Evaluation of China-Aster (Callistephus chinensis Nees.) in Sub-Tropical Region of West Bengal. Int.J.Curr.Microbiol.App.Sci. 9(06): 3726-3736. doi: https://doi.org/10.20546/ijcmas.2020.906.440 